\title{
PENGARUH INTELLECTUAL CAPITAL TERHADAP NILAI PASAR (MARKET VALUE) DENGAN PROFITABILITAS SEBAGAI VARIABEL MEDIASI PADA PERUSAHAAN RITEL YANG TERDAFTAR DI BURSA EFEK INDONESIA PERIODE 2012-2016
}

\author{
Richard Then \\ Akuntansi, Universita Bunda Mulia, Jakarta Utara, email:shen.shen30@yahoo.com
}

\begin{abstract}
ABSTRAK:
Saat ini pertumbuhan ekonomi di Indonesia mengalami perkembangan yang sangat pesat. Hal tersebut mengharuskan perusahaan untuk meningkatkanintellectual capital yang merupakan bagian dari aset tak berwujud untuk meningkatkan kinerja perusahaan. Penelitian ini berupaya memberikan pembuktian empiris pengaruhintellectual capital sebagai penggerak utama yang dapat meningkatkan profitabilitas dan nilai pasar perusahaan. Penelitian ini merupakan penelitian kuantitatif dengan pengambilan data sekunder. Populasi dan sampel adalah 20 perusahaan ritel yang terdaftar di Bursa Efek Indonesia (BEI) selama periode penelitian 2012-2016 yang diolah dengan menggunakan SmartPLS 3.0. Hasil penelitian ini menunjukkan bahwa intellectual capital berpengaruh secara signifikan terhadap profitabilitas dan nilai pasar, profitabilitas berpengaruh secara signifikan terhadap nilai pasar, serta profitabilitas mampu memediasi pengaruh intellectual capital terhadap nilai pasar. Novelti penelitian ini berupaya menguji efek mediasi ROA yang merupakan ukuran kinerja keuangan atas pengaruh intellectual capital terhadap nilai pasar untuk perusahaan ritel di Indonesia yang saat ini sedang mengalami goncangan secara global. Kontribusi penelitian diharapkan perusahaan mampu mengelola intellectual capitaluntuk meningkatkan kinerja.
\end{abstract}

Kata Kunci: Intellectual Capital, Profitabilitas, Nilai Pasar.

\begin{abstract}
:
Currently economic growth in Indonesia has experienced a very rapid growth. It requires companies to increase intellectual capital that is part of the intangible asset to improve the company's performance. This research is to provide empirical evidence of the influence of intellectual capital as the main driver that can improve profitability and market value of the company. This research is a quantitative research by taking secondary data. Populations and samples are 20 companies listed on the Indonesia Stock Exchange (IDX) during the 2012-2016 study period processed using SmartPLS 3.0. The results of this study indicate that intellectual capital has significant effect on profitability and market value, significant profitability to market value, and profitability able to mediate intellectual influence on market value. These new research aims to develop ROA which is one of intellectual intellectual basic form of market values for retail companies in Indonesia which is currently underway. Contribution of research expected company able to manage intellectual capital to improve performance.
\end{abstract}

Keywords:Intellectual Capital, Profitability, Market Value. 


\section{National Conference of Creative Industry: \\ Sustainable Tourism Industry for Economic Development}

Universitas Bunda Mulia, Jakarta, 5-6 September 2018

e-ISSN No: 2622 - 7436

\section{PENDAHULUAN}

Salah satu tujuan perusahaan yang terdaftar di bursa efek adalah meningkatkan nilai pasar dari saham yang beredar. Hal ini merupakan ukuran keberhasilan perusahaan dalam menjaga kepercayaan investor yang merupakan pemegang saham. Semakin tinggi nilai pasar, mencerminkan keberhasilan perusahaan dalam mengelola operasional untuk menghasilkan laba menjaga kepercayaan pemegang saham. Nimtrakoon (2015) menjelaskan bahwa, nilai pasar mengacu pada keseluruhan nilai saham yang dikeluarkan oleh perusahaan dinilai pada suatu waktu tertentu berdasarkan mekanisme pasar saham. Menurut Gitman et al. (2011) dalam mengukur nilai pasar dapat diukur dengan menggunakan market per book (M/B). Rasio tersebut dapat mengetahui seberapa besar harga pasar yang ada dipasar dibandingkan dengan nilai buku sahamnya dan dapat mencerminkan kemampuan investasi yang dimiliki oleh perusahaan. Namun banyak peneliti juga menggunakan Tobin's Q dalam mengukur nilai pasar, akan tetapi menurut Suherman (2017) pengukuran dengan menggunakan Tobin's Q memeng memberikan hasil yang akurat, akan tetapi perhitungan yang digunakan lebih sulit dibandingkan dengan market per book (M/B).

Nimtrakoon (2015) merupakan salah satu dari banyak peneliti yang menyatakan bahwa market value dipengaruhi oleh banyak variabel, salah satu variabel tersebut yaitu intellectual capital. Dalam konteks ini, jika perusahaan memiliki IC dan mengelolanya dengan baik, maka akan berdampak pada nilai pasar perusahaan. Dengan kata lain, jika pasar modalnya efisien, investor akan memberikan nilai yang lebih tinggi bagi perusahaan dengan nilai IC yang lebih besar. Selain hal tersebut, jika IC merupakan sumber daya yang berharga untuk keunggulan kompetitif, maka ia akan berkontribusi terhadap kinerja perusahaan (Ulum, 2017).Terdapat beberapa cara dalam pengukuran IC, salah satu model yang sangat populer di berbagai negara adalah Value Added Intellectual Coefficient (VAIC $^{\mathrm{TM}}$ ) yang dikembangkan oleh Pulic (1998). VAIC $^{\mathrm{TM}}$ sebagai suatu ukuran kinerja IC telah diuji dalam berbagai konteks industri dan negara. Sejumlah penelitian empiris telah menguji hubungan langsung antara IC dengan kinerja pasar (Ulum, 2017).

Pengelolaan intellectual capital tidak terlepas dari tujuan perusahaan, dimana perusahaan bertujuan dalam meningkatkan profitabilitas dalam mengoperasikan perusahaan tersebut (Fadri \& Wahidahwati, 2016). Profitabilitas merupakan kemampuan perusahaan untuk mendapatkan laba dalam suatu periode tertentu. Profitabilitas memiliki peranan yang sangat penting dalam struktur dan pengembangan perusahaan dikarenakan dapat mengukur kinerja dan keberhasilan suatu perusahaan. Beberapa penelitian yang menguji IC terhadap kinerja keuangan perusahaan antara lain : Suherman (2017), Agusta dan Adibawa (2017)Faza dan Hidayah (2014)

Tujuan pertama penelitian ini memberikan pembuktian empiris terdapat pengaruh IC terhadap nilai pasar dengan ukuran MtBV. Selain itu IC juga berpengaruh terhadap kinerja keuangan dengan ukuran ROA. Tujuan lain penelitian ini memberikan bukti empiris bahwa ROA sebagai kinerja keuangan mampu memediasi IC terhadap nilai pasar. Hal ini disebabkan karena informasi kinerja keuangan memberikan signal bagi nilai pasar (Ulum, 2017).

Masih terbatasnya penelitian mengenai pengaruh intellectual capital tarhadap nilai pasar terhadap nilai pasar dan profitabilitas dalam industri ritel. Hal ini menyebabkan penelitian ini masih menarik untuk diteliti, karena mengingat bahwa saat ini indutri bisnis dalam 


\section{National Conference of Creative Industry: \\ Sustainable Tourism Industry for Economic Development}

Universitas Bunda Mulia, Jakarta, 5-6 September 2018

e-ISSN No: 2622 - 7436

sektor ritel memiliki kontribusi yang besar terhadap perekonomian di Indonesia. Industri ritel merupakan salah satu jasa yang bergantung pada aset tidak berwujud untuk dapat bersaing dengan yang lain. Sebagai intermediari antara manufaktur dan konsumen akhir, industri ritel harus memiliki keunggulan bersaing dalam hal pengelolaan IC, mengingat saat ini pun industri ritel di Indonesia sedang mngalami goncangan bisnis.

\section{TINJAUAN PUSTAKA}

\section{Intellectual Capital}

Definisi yang berbeda-beda mengenai intellectual capital telah digambarkan oleh para ahli. Williams (2001) mengidentifikasikan intellectual capital sebagai berikut:

The enhanced value of firm attributable to assets, generally of an intangible nature, resulting from the company's organizational function, processes and information technology network, the competency and efficiency of its employees and its relationship with its customer. Intellectual capital assets are developed from (a) the creation of new knowledge and innovation; $(b)$ application of present knowledge to present issues and concerns that enhance employees and customers; (c) packaging, processing and transmission of knowledge; and $(d)$ the acquisition of present knowledge created through research and learning.

Bontis et al. (2000) menyatakan bahwa secara umum, para peneliti mengidentifikasi tiga konstruk utama dari modal intelektual, yaitu: human capital (HC), structural capital (SC), dan customer capital (CC). Menurut Bontis et al. (2000), secara sederhana HC mempresentasikan individual knowledge stock suatu organisasi yang dipresentasikan oleh karyawannya. HC merupakan kombinasi dari genetic inheritance, education, experience, and attitude tentang kehidupan dalam bisnis.

Lebih lanjut Bontis et al. (2000) menyebutkan bahwa SC meliputi seluruh non-human storehouse of knowledge dalam organisasi. Termasuk dalam hal ini adalah database, organisational charts, process manual, strategies, routines dan segala hal yang membuat nilai perusahaan lebih besar daripada nilai materialnya. Sedangkan tema utama CC adalah pengetahuan yang melekat dalam marketing channels dan customer relationship di mana suatu organisasi mengembangkannya melalui jalannya bisnis (Bontis et al., 2000).

\section{Profitabilitas}

Menurut Sartono (2010) profitabilitas merupakan kemampuan perusahaan dalam mendapatkan laba yang berhubungan dengan penjualan, total aktiva dan modal sendiri. Menurut Bringham \& Houston (2010) profitabilitas adalah hasil akhir dari sejumlah kebijakan dan keputusan yang dilakukan oleh perusahaan. Profitabilitas merupakan salah satu indikator keberhasilan perusahaan untuk dapat menghasilkan laba sehingga semakin tinggi profitabilitas maka semakin tinggi pula kemampuan perusahaan dalam menghasilkan laba bagi perusahaan tersebut.

Menurut pendapat para ahli tersebut dapat disimpulkan bahwa profitabilitas adalah kemampuan suatu perusahaan dalam menghasilkan laba dari proses kegiatan bisnis perusahaan melalui berbagai keputusan dan kebijakan manajemen.

Ada beberapa rasio yang digunakan dalam pengukuran profitabilitas. Menurut Horne \& Wachowics (2009)Return on Assets merupakan rasio yang mengukur kemampuan suatu 


\section{National Conference of Creative Industry: \\ Sustainable Tourism Industry for Economic Development}

Universitas Bunda Mulia, Jakarta, 5-6 September 2018 e-ISSN No: 2622 - 7436

perusahaan dalam menghasilkan laba dengan berdasarkan tingkat aset tertentu, sedangkan Return on Equity dengan berdasarkan tingkat ekuitas tertentu pada suatu perusahaan.

\section{Nilai Pasar (Market Value)}

Nilai pasar adalah harga saham yang terjadi di pasar bursa tertentu yang terbentuk oleh permintaan dan penawaran saham oleh para pelaku pasar (Sejati \& Prastiwi, 2015)

Nilai pasar (market value) dapat diukur dengan beberapa pengukuran, salah satunya dengan market to book value ratio(Pangestu \& Wijaya, 2014).

Market to book value merupakan tolak ukur dalam menentukan seberapa jauh perusahaan tersebut memilih peluang investasi. Market to book value mencerminkan seberapa besar pasar menilai perusahaan dapat memanfaatkan modalnya dalam menjalankan usaha untuk memenuhi tujuan perusahaan. Semakin besar perusaahan dapat mengelola modalnya dengan baik, maka kesempatan perusahaan untuk bertumbuh akan semakin tinggi sehingga dapat menarik investor untuk menanamkan dananya kedalam perusahaan tersebut.

\section{HIPOTESIS}

Menurut resource based theory sumber daya berpotensi menciptakan keunggulan kapabilitas prima yang akan mendorong terbentuknya keunggulan kompetitif yang menjadi suatu strategi bagi perusahaan dalam memenangkan suatu persaingan bisnis. Kapabilitas prima yang berasal dari sumber daya tersebut akan meningkatkan market value melalui ketiga komponen intellectual capital yaitu, layanan produk dan jasa yang dirasakan oleh customer akibat adanya peningkatan human capital dan structural capital. Dalam penelitian yang dilakukan oleh Agusta dan Adiwibawa (2017) menunjukkan adanya pengaruh intellectual capital terhadap nilai pasar perusahaan. Penelitian lainnya yang dilakukan oleh Suherman (2017), menunjukkan bahwa intellectual capital memiliki pengaruh yang tidak kuat terhadap market value.

Sesuai dengan resouce based theory dimana perusahaan yang mampu mengelola intellectual capital dengan baik maka perusahaan tersebut akan memiliki keunggulan kompetitif serta diyakini mampu menciptakan nilai tambah yang berpengaruh terhadap peningkatan kinerja keuangan perusahaan. Menurut Barney (1991) intellectual capital diakui sebagai aset perusahaan karena mampu menghasilkan keunggulan kompetitif dan kinerja keuangan yang superior. Semakin baik perusahaan dalam mengelola komponenkomponen yang ada dalam intellectual capital, menunjukkan semakin baik pula perusahaan dalam pengelolaan aset.

Ada beberapa rasio yang digunakan dalam pengukuran profitabilitas. Menurut Horne \& Wachowics (2009)Return on Assets merupakan rasio yang mengukur kemampuan suatu perusahaan dalam menghasilkan laba dengan berdasarkan tingkat aset tertentu, sedangkan Return on Equity dengan berdasarkan tingkat ekuitas tertentu pada suatu perusahaan.

Penelitian yang dilakukan oleh Faza \& Hidayah (2014) menunjukkan bahwa intellectual capital berpengaruh positif terhadap profitabilitas perusahaan. Selanjutnya, berdasarkan penelitian yang telah dilakukan oleh Fadri \& Wahidahwati (2016) menunjukan adanya pengaruh positif antara intellectual capital terhadap profitabilitas perbankan syariah. Selain itu, penelitian yang dilakukan oleh Halim \& Faisal (2016) juga menujukkan adanya pengaruh intellectual capital terhadap profitabilitas perusahaan sektor keuangan.Penelitian yang dilakukan oleh Yulianto \& Subardjo (2017), membuktikan bahwa profitabilitas memiliki pengaruh negatif terhadap nilai pasar pada perusahaan otomotif yang terdaftar di Bursa Efek Indonesia.Selanjutnya penelitian yang dilakukan 


\section{National Conference of Creative Industry: \\ Sustainable Tourism Industry for Economic Development}

Universitas Bunda Mulia, Jakarta, 5-6 September 2018

e-ISSN No: 2622 - 7436

oleh Hermuningsih (2013), membuktikan bahwa profitabilitas berpengaruh positif dan signifikan terhadap nilai perusahaan. Selain itu Rahmawati, Topowijono, \& Sulasmiyati (2015), juga membuktikan dalam penilitiannya bahwa profitabilitas memiliki pengaruh signifikan dengan arah positif terhadap nilai perusahaan.

Berdasarkan penelitian terdahulu yang dilakukan oleh beberapa peneliti seperti: Agusta dan Adiwibawa (2017) menunjukkan adanya pengaruh intellectual capital terhadap nilai pasar perusahaan. Penelitian lainnya yang dilakukan oleh Suherman (2017), menunjukkan bahwa intellectual capital memiliki pengaruh yang tidak kuat terhadap market value. Serta penelitian yang dilakukan oleh Yulianto \& Subardjo (2017), membuktikan bahwa profitabilitas memiliki pengaruh negatif terhadap nilai pasar pada perusahaan otomotif yang terdaftar di Bursa Efek Indonesia, maka penulis membangun hipotesis keempat dalam penelitian ini adalah sebagai berikut:

H1: Intellectual Capital berpengaruh terhadap market value.

H2: Intellectual capital berpengaruh terhadap profitabilitas.

H3: Profitabilitas berpengaruh terhadap nilai pasar (market value).

H4: Profitabilitas memediasi pengaruh intellectual capital terhadap nilai pasar (market value).

\section{METODE PENELITIAN}

Subjek dari penelitian ini adalah perusahaan ritel yang terdapat di Bursa Efek Indonesia periode 2012-2016. Objek yang menjadi penelitian dalam penulisan ini adalah laporan keuangan tahunan yang melihat intellectual capital, nilai pasar (market value), serta profitabilitas pada perusahaan ritel yang terdaftar di Bursa Efek Indonesia periode 20122016. Penulisan dalam penelitian ini menggunakan jenis penelitian dengan pendekatan kuantitatif dimana data tersebut menggunakan angka sebagai pendekatan penelitiannya. Dalam penelitian ini, peneliti menggunakan teknik studi pustaka dan studi dokumenter. Dimana dalam teknik studi pustaka digunakan sebagai landasan teori yang akan digunakan dalam menganalisi kasus. Populasi dalam penelitian ini adalah perusahaan ritel yang telah go public dan terdaftar dalam Bursa Efek Indonesia (BEI) periode 2012-2016. Pemilihan sampel dilakukan dengan menggunakan teknik purposive sampling. Variabel dalam penelitian ini terdiri dari tiga macam, yaitu variabel independen, variabel dependen dan variabel moderasiVariabel yang digunakan dalam penelitian ini adalah:

1. Variabel independen (bebas), yaitu Intellectual Capital (X)

2. Variabel dependen (terikat), yaitu Nilai Pasar (Market Value) (Y)

3. Variabel mediasi (antara), yaitu Profitabilitas $(\mathrm{Z})$

Metode analisis data yang digunakan dalam penelitian ini adalah analisis kuantitatif dengan menggunakan model SEM (Structural Equation Modeling) atau model persamaan struktural dengan program SmartPLS 3.0 (Partial Least Square).

\section{HASIL PENELITIAN DAN PEMBAHASAN}

\section{Model Pengukuran (Outer Model)}

Analisa outer model dilakukan untuk memastikan bahwa measurement yang digunakan layak untuk dijadikan pengukuran (valid dan reliabel). Berikut disajikan evaluasi hasil model dalam penelitian ini: 


\section{Gambar 4.1}

Model Pengukuran (Outer Model)

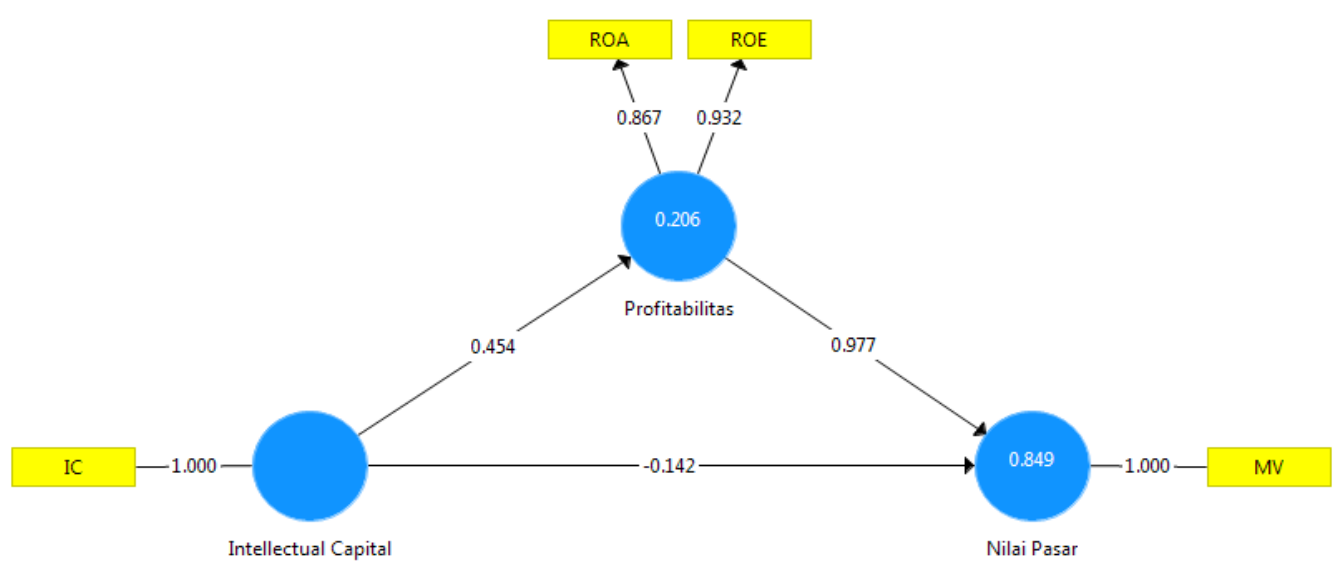

Uji yang dilakukan pada outer model adalah sebagai berikut:

1. Validitas Konvergen

Nilai yang diharapkan dala uji berikut adalah $>0.6$. Dari gambar di atas dapat dilihat bahwa semua nilai loading factor dari setiap variabel laten sudah berada di atas 0.6. Selain dilihat dari loading factor, validitas konvergenjuga dapat dilihat dari nilai Average Variance Extracted (AVE). Nilai AVE yang diharapkan adalah lebih besar dari 0.5 .

Tabel 4.2.1

Penyajian Hasil Construct Reliability and Validity

\begin{tabular}{|c|c|c|c|c|}
\hline & Cronbach's Alpha & rho_A & Composite Reliability & Average Variance Extracted (AVE) \\
\hline Intellectual Ca... & 1.000 & 1.000 & 1.000 & 1.000 \\
\hline Nilai Pasar & 1.000 & 1.000 & 1.000 & 1.000 \\
\hline Profitabilitas & 0.772 & 0.827 & 0.895 & 0.810 \\
\hline
\end{tabular}

Sumber: Data diolah dengan menggunakan SmartPLS 3.0

Pada penelitian ini, nilai AVE masing-masing variabel berada diatas 0.5. Oleh karena itu, tidak terdapat permasalahan dalam validitas konvergen pada model yang diuji.

2. Validitas Diskriminan

Validitas diskriminan dapat di uji dengan melihat tabel cross loading.

Tabel 4.2.2

Penyajian Hasil Discriminant Validity

\begin{tabular}{|l|r|r|r|} 
& Intellectual Ca... & Nilai Pasar & Profitabilitas \\
\hline IC & 1.000 & 0.301 & 0.454 \\
\hline MV & 0.301 & 1.000 & 0.913 \\
\hline ROA & 0.507 & 0.592 & 0.867 \\
\hline ROE & 0.341 & 0.995 & 0.932 \\
\hline
\end{tabular}


Sumber: Data diolah dengan menggunakan SmartPLS 3.0

Variabel dikatakan valid apabila nilai loading dari masing-masing item terdapat konstruk lebih besar daripada nilai cross loading (nilai loading pada variabel laten lain). Dari haril analisa cross loading dapat dilihat bahwa tidak terdapat permasalahan pada variabel intellectual capital dan market value akan tetapi terdapat permasalahan pada variabel profitabilitas. Dalam variabel profitabilitas dengan pengukuran ROA dapat dilihat tidak terdapat permasalahan akan tetapa pada pengukuran menggunakan ROE dapat dilihat bahwa nilai cross loading lebih besar dibandingkan dengan nilai loading. Akan tetapi hal ini tidak akan menjadi permasalahan, dikarenakan selisih pada kedua nilai relatif kecil. Selain itu, pada saat melakukan uji validitas konvergen tidak ditemukan permalahan.

3. Uji Reliabilitas

Uji reliabilitas dilakukan dengan menggunakan indikator Cronbach's Alpha dan Composite Reliability. Untuk kedua indikator tersebut titik cut-off adalah 0.6 untuk Cronbach's Alpha dan 0.7 untuk Composite Reliability. Dapat dilihat pada tabel 4.2.1 diatas bahwa indikator Cronbach's Alpha dan Composite Reliability sudah memenuhi syarat.

\section{Model Struktural (Inner Model)}

Analisa inner model (model struktural) dilakukan untuk memastikan bahwa model struktural yang dibangun akurat. Evaluasi inner model dapat dilakukan dengan tiga cara yaitu dengan melihat dari $\mathrm{R}^{2}, \mathrm{Q}^{2}$, dan $\mathrm{GoF}$.

1. $\mathrm{R}$-Square $\left(\mathrm{R}^{2}\right)$

Menurut Chin (1998) dalam Ghozali dan Latan (2015), nilai R-square sebesar 0.67 (kuat), 0.33 (moderat), 0.19 (lemah).

Tabel 4.2.3

\begin{tabular}{|l|r|r|}
\multicolumn{3}{c}{ Penyajian Hasil R-Square } \\
& R Square & R Square Adjus... \\
\hline Nilai Pasar & 0.849 & 0.845 \\
\hline Profitabilitas & 0.206 & 0.196 \\
\hline
\end{tabular}

Sumber: Data diolah dengan menggunakan SmartPLS 3.0

Tabel diatas menunjukkan bahwa intellectual capital mampu menjelaskan variasi pada market value sebesar $84.9 \%$ sedangkan sisanya dijelaskan oleh variabel lain di luar model. Hal tersebut menunjukkan bahwa koefisien determinasi model kuat. Dan intellectual capital dan market value mampu menjelaskan variasi pada profitabilitas sebesar 20.6\%, yang berarti koefisien determinasi model ini lemah.

2. Q-Square

Uji ini dilakukan untuk mengetahui kapabilitas prediksi dengan prosedur blinfolding. Apabila nilai yang didapatkan 0.02 (kecil), 0.15 (sedang), 0.35 (besar). Uji q-square hanya dapat dilakukan untuk konstruk endogen dengan indikator reflektif. Rumus menghitung $\mathrm{Q}^{2}$ adalah sebagai berikut:

$\mathrm{Q}^{2}=1-\left(1-\mathrm{R}_{1}^{2}\right)\left(1-\mathrm{R}_{2}^{2}\right) \ldots\left(1-\mathrm{R}_{\mathrm{p}}^{2}\right) \ldots$.

$\mathrm{Q}^{2}=1-(1-0.849)(1-0.206)$

$\mathrm{Q}^{2}=0.8801$

Nilai tersebut mengartikan bahwa kapabilitas prediksi model ini besar. 


\section{Goodness of Fit $(\mathrm{GoF})$}

Uji ini dipergunakan untuk mengetahui kesesuaian model. Dalam GoF apabila nilai yang didapatkan 0.1 (rendah), 0.25 (sedang), 0.36 (tinggi). rumus untuk menghitung GoF adalah sebagai berikut:

$$
\begin{aligned}
& \text { GoF }=\sqrt{\overline{\mathrm{AVE}} \times \overline{\mathrm{R}^{2}}} \\
& \mathrm{GoF}=\sqrt{\frac{1+1+0.810}{3} \times \frac{0.849+0.206}{2}} \\
& \mathrm{GoF}=\sqrt{0.93667 \times 0.5275} \\
& \mathrm{GoF}=0.5105
\end{aligned}
$$

Nilai tersebut berada ditingkat tinggi, sehingga model ini dapat dikatakan baik untuk memprediksi. Oleh sebab itu pengujian hipotesa dapat dilakukan.

\section{Uji Hipotesis}

Suatu variabel dikatakan berpengaruh terhadap variabel lain apabila nilai p-value

\begin{tabular}{|c|c|c|c|c|c|}
\hline & Original Sampl... & Sample Mean (... & Standard Devia... & T Statistics $(\mid 0 \ldots$ & P Values \\
\hline Intellectual Capital -> Nilai Pasar & 0.301 & 0.343 & 0.114 & 2.647 & 0.008 \\
\hline Intellectual Capital -> Profitabilitas & 0.454 & 0.476 & 0.105 & 4.340 & 0.000 \\
\hline Profitabilitas -> Nilai Pasar & 0.977 & 0.942 & 0.120 & 8.169 & 0.000 \\
\hline
\end{tabular}
hubungan/jalur berada di bawah 0.05 .

Tabel 4.2.4

\section{Penyajian Hasil Total Effects}

Sumber: Data diolah dengan menggunakan SmartPLS 3.0

Dapat dilihat dari tabel diatas dapat disimpulkan bahwa:

1. Pengaruh Intellectual Capital terhadap Nilai Pasar (Market Value)

Dari tabel diatas nilai p-value untuk pengujian intelelctual capital terhadap market value menunjukkan nilai probabiliatas 0.008 dimana nilai probabilitas lebih kecil dari 0.05 , sehingga dapat disimpulkan $\mathrm{H}_{1}$ diterima. Secara teori intellectual capital yang dikelola secara efisien oleh perusahaan akan meningkatkan apresiasi pasar terhadap nilai pasar sehingga dapat meningkatkan market to book value. Penelitian ini mendukung hasil penelitian sebelumnya yang dilakukan oleh Agusta dan Adiwibawa (2017) serta Suherman (2017).

2. Pengaruh Intellectual Capital terhadap Profitabilitas

Penelitian Faza dan Hidayah (2014) serta Fadri dan Wahidahwati (2016) menyatakan bahwa intellectual capital memiliki pengaruh terhadap profitabilitas. Sesuai dengan penelitian sebelumnya dalam penelitian yang dilakukan nilai p-value diatas untuk pengujian intellectual capital terhadap profitabilitas menunjukkan nilai profitabilitas sebesar 0.000 dimana nilai tersebut lebih kecil dibandingkan 0.05 , sehingga dapat disimpulkan bahwa $\mathrm{H}_{2}$ diterima. Hal tersebut menunjukkan bahwa semakin baik perusahaan dalam mengelola ketiga komponen intellectual capital, maka akan semakin baik pula perusahaan dalam mengelola aset maupun ekuitas untuk mendapatkan keuntungan yang maksimal.

3. Pengaruh Profitabilitas terhadap Nilai Pasar (Market Value)

Dapat dilihat dari tabel diatas nilai p-value untuk pengujian profitabilitas terhadap market value menunjukkan nilai sebesar 0.000 dimana nilai tersebut lebih kecil 
dibandingkan 0.05. Dengan demikian dapat dinyatakan bahwa profitabilitas berpengaruh signifikan terhadap market value, sehingga $\mathrm{H}_{3}$ diterima. Hasil penelitian ini sesuai dengan penelitian sebelumnya yang dilakukan oleh Rahmawati, Topowijono, dan Sulasmiyati (2015).

4. Pengaruh Intellectual Capital terhadap Nilai Pasar (Market Value) dengan Profitabilitas sebagai Mediasi

Untuk melihat apakah profitabilitas mampu memediasi hubungan antara intellectual dengan market value, menurut Pardede dan Manurung (2014) yaitu dengan mengkalikan loading factor intellectual capital terhadap profitabilitas yaitu sebesar 0.381 dan loading factor profitabilitas terhadap market value yaitu sebesar 0.948, sehingga diperoleh hasil $0.381 \times 0.948=0.361$. Kemudian hasil tersebut dibandingkan dengan hasil loading factor hubungan secara langsung antara intellectual capital dengan market value yang menunjukkan hasil -0.060. Dari hasil tersebut dapat dinyatakan dengan adanya variabel mediasi yaitu variabel profitabilitas membuat hubungan antara intellectual capital dengan market value menjadi lebih baik dibandingkan dengan tidak adanya mediasi, oleh sebab itu maka $\mathrm{H}_{4}$ diterima.

\section{Uji Sensitivitas}

\section{Model Pengukuran (Outer Model)}

Analisa outer model dilakukan untuk memastikan bahwa measurement yang digunakan layak untuk dijadikan pengukuran (valid dan reliabel). Berikut disajikan evaluasi hasil model dalam penelitian ini untuk uji sensitivitas:

\section{Gambar 4.2}

\section{Model Pengukuran (Outer Model) Uji Sensitivitas}

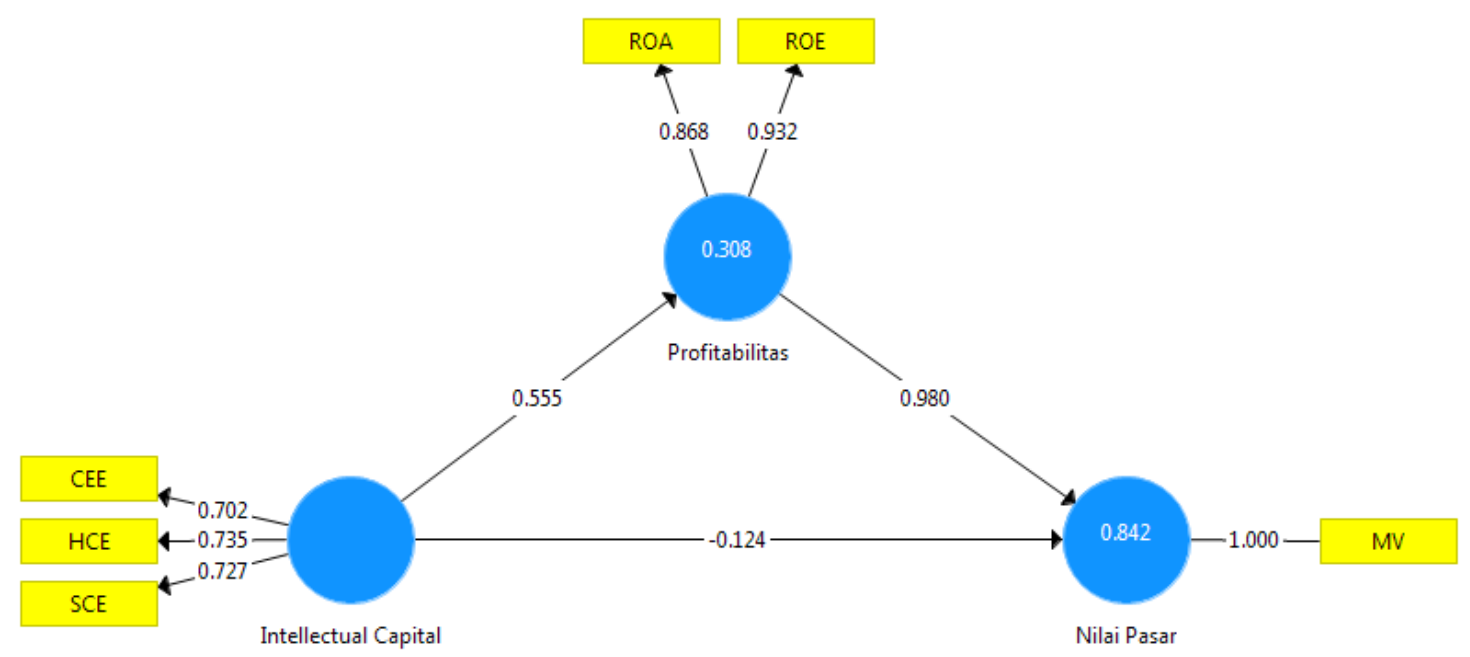

Uji yang dilakukan pada outer model adalah sebagai berikut:

1. Validitas Konvergen

Nilai yang diharapkan dala uji berikut adalah sebesar $>0.6$. dari gambar di atas dapat dilihat bahwa semua nilai loading factor dari setiap variabel laten sudah berada di atas 0.6 .

2. Validitas Diskriminan

Validitas diskriminan dapat di uji dengan melihat tabel cross loading 
Tabel 4.3.1

Penyajian Hasil Discriminant Validity Uji Sensitivitas

\begin{tabular}{l|r|r|r|} 
& Intellectual C... & Nilai Pasar & Profitabilitas \\
\hline CEE & 0.702 & 0.462 & 0.471 \\
\hline HCE & 0.735 & 0.134 & 0.307 \\
\hline MV & 0.420 & 1.000 & 0.912 \\
\hline ROA & 0.559 & 0.592 & 0.868 \\
\hline ROE & 0.460 & 0.995 & 0.932 \\
\hline SCE & 0.727 & 0.167 & 0.349 \\
\hline
\end{tabular}

Sumber: Data diolah dengan menggunakan SmartPLS 3.0

Variabel dikatakan valid apabila nilai loading dari masing-masing item terdapat konstruk lebih besar daripada nilai cross loading (nilai loading pada variabel laten lain). Dari haril analisa cross loading dapat dilihat bahwa tidak terdapat permasalahan pada variabel intellectual capital dan market value akan tetapi terdapat permasalahan pada variabel profitabilitas. Dalam variabel profitabilitas dengan pengukuran ROA dapat dilihat tidak terdapat permasalahan akan tetapa pada pengukuran menggunakan ROE dapat dilihat bahwa nilai cross loading lebih besar dibandingkan dengan nilai loading. Akan tetapi hal ini tidak akan menjadi permasalahan, dikarenakan selisih pada kedua nilai relatif kecil. Selain itu, pada saat melakukan uji validitas konvergen tidak ditemukan permalahan.

3. Uji Reliabilitas

Untuk memastikan bahwa tidak tedapat masalah terkait pengukuran maka langkah terakhir dalam evaluasi outer model adalah menguji reliabilitas dari miodel. Uji reliabilitas dilakukan dengan menggunakan indikator Cronbach's Alpha dan Composite Reliability. Untuk kedua indikator tersebut titik cut-off adalah 0.6 untuk Cronbach's Alpha dan 0.7 untuk Composite Reliability. Kedua ukuran ini dipergunakan untuk melihan kehandalan pertanyaan-pertanyaan yang menyusun suatu variabel laten.

\section{Tabel 4.3.2}

\section{Penyajian Hasil Construct and Validity Uji Sensitivitas}

\begin{tabular}{l|r|r|r|r|} 
& Cronbach's Alpha & rho_A & Composite Rel... & Average Varian... \\
\hline Intellectual Ca... & 0.609 & 0.537 & 0.765 & 0.520 \\
\hline Nilai Pasar & 1.000 & 1.000 & 1.000 & 1.000 \\
\hline Profitabilitas & 0.772 & 0.825 & 0.895 & 0.811 \\
\hline
\end{tabular}

Sumber: Data diolah dengan menggunakan SmartPLS 3.0

Dapat dilihat pada tabel diatas bahwa indikator Cronbach's Alpha dan Composite Reliability sudah memenuhi syarat.

Model Struktural (Inner Model) 
Evaluasi inner model dapat dilakukan dengan tiga cara. Ketiga cara tersebut adalah dengan melihat dari $\mathrm{R}^{2}, \mathrm{Q}^{2}$, dan GoF.

1. R-Square $\left(\mathrm{R}^{2}\right)$

Menurut Chin (1998) dalam Ghozali dan Latan (2015), nilai R-square sebesar 0.67

(kuat), 0.33 (moderat), 0.19 (lemah).

Tabel 4.3.1

\begin{tabular}{|c|c|c|}
\hline \multicolumn{3}{|c|}{ Penyajian Hasil R-Square Uji Sensitivitas } \\
\hline & R Square & R Square Adjus... \\
\hline Nilai Pasar & 0.842 & 0.838 \\
\hline Profitabilitas & 0.308 & 0.299 \\
\hline
\end{tabular}

Sumber: Data diolah dengan menggunakan SmartPLS 3.0

Tabel diatas menunjukkan bahwa intellectual capital mampu menjelaskan variasi pada market value sebesar $84.2 \%$ sedangkan sisanya dijelaskan oleh variabel lain di luar model. Hal tersebut menunjukkan bahwa koefisien determinasi model kuat. Dan intellectual capital dan market value mampu menjelaskan variasi pada profitabilitas sebesar 30.8\%, yang berarti koefisien determinasi model ini lemah.

2. Q-Square

Uji ini dilakukan untuk mengetahui kapabilitas prediksi dengan prosedur blinfolding. Apabila nilai yang didapatkan 0.02 (kecil), 0.15 (sedang), 0.35 (besar). Uji qsquarehanya dapat dilakukan untuk konstruk endogen dengan indikator reflektif. Rumus menghitung $\mathrm{Q}^{2}$ adalah sebagai berikut:

$\mathrm{Q}^{2}=1-\left(1-\mathrm{R}_{1}^{2}\right)\left(1-\mathrm{R}_{2}^{2}\right) \ldots\left(1-\mathrm{R}_{\mathrm{p}}^{2}\right) \ldots$

$\mathrm{Q}^{2}=1-(1-0.842)(1-0.308)$

$\mathrm{Q}^{2}=0.8907$

Nilai tersebut mengartikan bahwa kapabilitas prediksi model ini besar.

3. Goodness of Fit (GoF)

Uji ini dipergunakan untuk mengetahui kesesuaian model. Dalam GoF apabila nilai yang didapatkan 0.1 (rendah), 0.25 (sedang), 0.36 (tinggi). rumus untuk menghitung GoF adalah sebagai berikut:

$$
\begin{aligned}
& \text { GoF }=\sqrt{\overline{\mathrm{AVE} \times \overline{\mathrm{R}^{2}}}} \\
& \mathrm{GoF}=\sqrt{\frac{0.520+1+0.811}{3} \times \frac{0.842+0.308}{2}} \\
& \mathrm{GoF}=\sqrt{0.777 \times 0.575} \\
& \mathrm{GoF}=0.5069
\end{aligned}
$$

Nilai tersebut berada ditingkat tinggi, sehingga model ini dapat dikatakan baik untuk memprediksi.

\section{KESIMPULAN DAN IMPLIKASI}

Penelitian ini menguji bagaimana pengaruh intellectual capital terhadap nilai pasar (market value) dengan profitabilitas sebagai variabel mediasi. Berdasarkan hasil penelitian, analisis dan pembahasan yang dilakukan, dapat disimpulkan sebagai berikut: 


\section{National Conference of Creative Industry: \\ Sustainable Tourism Industry for Economic Development}

Universitas Bunda Mulia, Jakarta, 5-6 September 2018

e-ISSN No: 2622 - 7436

1. Hasil analisis data menunjukkan bahwa intellectual capital berpengaruh signifikan terhadap nilai pasar (market value

2. Hasil analisis data menunjukkan bahwa intellectual capital berpengaruh signifikan terhadap profitabilitas.

3. Hasil analisis data menunjukkan bahwa profitabilitas berpengaruh signifikan terhadap nilai pasar (market value).

4. Hasil analisis data menunjukkan bahwa intellectual capital berpengaruh terhadap nilai pasar (market value) dengan adanya profitabilitas sebagai variabel mediasi.

Berdasarkan hasil penelitian yang telah dilakukan, maka saran yang dapat diberikan:

1. Bagi Peneliti Berikutnya

Penelitian berikutnya dapat meneliti tidak hanya pada industri ritel saja, dapat menambahkan variabel-variabel lainnya dan menambah pengukuran pada masingmasing variabel, data sekunder yang digunakan tidak hanya diperoleh melalui website

2. Bagi Perusahaan

Bagi perusahaan ritel diharapkan dapat mengelola dan mengembangkan komponen intellectual capital dengan lebih baik lagi guna meningkatkan kontribusi terhadap performa perusahaan melalui profitabilitas dan nilai pasar (market value).

3. Bagi Investor

Bagi investor dan calon investor diharapkan untuk memperhatikan intellectual capital perusahaan sebagai pertimbangan dalam investasi.

\section{DAFTAR PUSTAKA}

Agusta, A., \& Adiwibawa, A. S. (2017). Analisis Pengaruh Modal Intelektual terhadap Profitabilitas, Produktifitas, dan Penilaian Pasar Perusahaan (Studi Kasus pada 35 Perusahaan LQ-45 di Bursa Efek Indonesia periode 2012-2014). Diponegoro Journal of Accounting Volume 6, Nomor 7, 1-11.

Bontis, N., Keow, W. C., \& Richardson, S. (2000). Intellectual capital and business performance in Malaysian industries. Journal of Intellectual Capital Vol. 1 No. 1 , 85-100.

Fadri, Z., \& Wahidahwati. (2016). Pengaruh Intellectual Capital terhadap Profitabilitas dan Produktivitas pada Perbankan Syariah di Indonesia. Jurnal Ilmu dan Riset Akuntansi Volume 5, Nomor 11, 1-18.

Faza, M. F., \& Hidayah, E. (2014). Pengaruh Intellectual Capital terhadap Profitabilitas, Produktivitas, dan Nilai Perusahaan pada Perusahaan Perbankan yang terdaftar di Bursa Efek Indonesia (BEI). EKBISI, Vol. VIII, No. 2, 186-199.

Ghozali, I., \& Latan, H. (2015). Partial Least Squares: Konsep, Teknik dan Aplikasi Menggunakan Program SmartPLS 3.0 untuk Penelitian Empiris. Semarang: Badan Penerbit Universitas Diponegoro.

Gitman, L. J., Juchau, R., \& Flanagan, J. (2011). Principles of Managerial Finance. Australia: Pearson.

Halim, A., \& Faisal, H. B. (2016). Pengaruh Intellectual Capital terhadap Profitabilitas dan Dampaknya terhadap Harga Saham Perusahaan Sektor Keuangan yang 


\section{National Conference of Creative Industry: \\ Sustainable Tourism Industry for Economic Development}

Universitas Bunda Mulia, Jakarta, 5-6 September 2018 e-ISSN No: 2622 - 7436

terdaftar di Bursa Efek Indonesia (BEI). Jurnal Bisnis dan Ekonomi (JBE), 124141.

Hermuningsih, S. (2013). Pengaruh Profitabilitas, Growth Opportunity, Struktur Modal terhadap Nilai Perusahaan pada Perusahaan Publik di Indonesia. Bulletin Ekonomi Moneter dan Perbankan, 127-148.

Horne, J. C., \& Wachowics, JR, J. M. (2009). Prinsip-prinsip Manajemen Keuangan, Edisi 12 Buku 1. Jakarta: Salemba Empat.

Nimtrakoon, S. (2015). The Relationship Between Intellectual Capital, Firm's Market Value and Financial Performance. Journal of Intellectual Capital Vol. 16, No. 3, 587-618.

Pangestu, A. D., \& Wijaya, R. E. (2014). Pengaruh Intellectual Capital terhadap Market Value dan Kineja Keuangan. Jurnal Akuntansi \& Investasi Vol. 15 No. 7, 90-100.

Pardede, R., \& Manurung, R. (2014). Analisis Jalur (Path Analysis): Teori dan Aplikasi dalam Riset Bisnis. Jakarta: PT Rineka Cipta.

Rahmawati, A. D., Topowijono, \& Sulasmiyati, S. (2015). Pengaruh Ukuran Perusahaan, Profitabilitas, Struktur Modal, dan Keputusan Investasi terhadap Nilai Perusahaan. Jurnal Administrasi Bisnis (JAB), Vol. 23 No. 2, 1-7.

Sejati, B. P., \& Prastiwi, A. (2015). Pengaruh Pengungkapan Sustainabiliti Report terhadap Kinerja dan Nilai Perusahaan. Diponegoro Journal of Accounting Volume 4, Nomor 1, 1-12.

Suherman, R. (2017). The Impact of Intellectual Capital toword Firm's Profitability and Market Value of Retail Companies Listed in Indonesia Stock Exchange (IDX) from 2013-2016). iBuss Management Vol. 5, No. 1, 98-112.

Ulum, I. (2017). INTELLECTUAL CAPITAL: Model Pengukuran, Framework Pengungkapan, dan Kinerja Organisasi. Malang: Universitas Muhammadiyah Malang.

Williams, S. M. (2001). Is ntellectual capital performance and disclosure practices related? Journal of Intellectual Capital Vol. 2 No. 3, 192-203.

Yulianto, F. C., \& Subardjo, A. (2017). Pengaruh Likuiditas, Solvabilitas, Aktivitas dan Profitabilitas terhadap Nilai Pasar. Jurnal Ilmu dan Riset Akuntansi Volume 6, Nomor 1, 187-202. 